\title{
A simple technique using 'dialysable' thyroxine for assessment of thyroid status
}

\author{
T. M. D. GIMLETTE
}

From the Radio-Isotope Laboratory, St. Thomas's Hospital, London

SYNOPSIS A simple method for assessing thyroid status is described in which the percentage radioactive thyroxine dialysed through a semi-permeable membrane between plasma samples estimated. The results compare favourably with other tests in vitro.

Two factors which influence thyroid status are the plasma content of thyroid hormone (mainly thyroxine) and the binding capacity of the thyroxinebinding protein; these dispose the quantity of thyroxine available to the tissues. Unfortunately neither protein-bound iodine or plasma thyroxine (Ekins, 1960) nor thyroxine-binding protein capacity (Robbins, 1956) are very simple to estimate as a routine. The quantity of thyroxine not bound to protein, or available, is too small to be estimated directly. By the addition of a small trace of ${ }^{131} \mathrm{I}$ labelled thyroxine to plasma it is possible to estimate the proportion of total thyroxine which is free, or available, by dialysis from plasma to buffer solution (Sterling and Hegedus, 1962) and this has been found to give a good indication of thyroid status. The technique is, however, somewhat exacting since the proportion of thyroxine ${ }^{131}$ I which is dialysable from plasma to buffer is exceedingly small, owing to the high affinity of thyroxine-binding protein for thyroxine. It is easier to estimate the proportion of a trace of ${ }^{131}$ I thyroxine which is dialysable in a given time across a semi-permeable membrane separating two plasma samples (Christensen, 1959). A simple technique is described which has proved satisfactory as a routine test of thyroid status.

\section{METHOD}

Visking cellophane tubing ${ }^{1}$ in lengths of $25 \mathrm{~cm}$. of $8 / 32$ in. $(0.63 \mathrm{~cm}$.) bore were prepared by soaking and washing in distilled water, then lightly blotted and a knot tied in one end. Into the open end was pipetted $2 \mathrm{ml}$. of plasma with an added tracer quantity of ${ }^{131}$ I thyroxine (not less than $20 \mathrm{~m} \mu \mathrm{c}$. of ${ }^{131} \mathrm{I}$ and not more than $20 \mathrm{~m} \mu \mathrm{g}$. of thyroxine in a volume of $0.03 \mathrm{ml}$.). The tubing was closed with a second knot, doubled so that the fluid level in the

${ }^{1}$ Hudes Manufacturing Co.

Received for publication 30 April 1963. two halves was the same, and placed in a $1.6 \times 10 \mathrm{~cm}$. glass test tube into which $2 \mathrm{ml}$. of the same plasma without added ${ }^{131}$ I thyroxine had first been pipetted, the tubiag being pushed down so that the level of plasma inside arast out were the same (Fig. 1). The test tube was closed witha plastic closure and incubated for 16 hours at $37^{\circ} \mathrm{C}$. in $-\mathrm{a}$ water bath. After incubation the test tube was counted on a well scintillation counter, giving the total counts $x$ from thyroxine ${ }^{131}$. The tubing was then removed from the test tube, the residual $2 \mathrm{ml}$. of plasma made up to $5 \mathrm{ni}$. with distilled water and shaken with $1.5 \mathrm{ml}$. of Amberlite IRA-400 resin for 10 minutes to remove free iodide (Owen, 1960). Into a second test tube $4 \mathrm{ml}$. supernata was pipetted and counted in the well scintillation counte? giving the counts $y$ from dialysed thyroxine ${ }^{131}$.

Then 'dialysable thyroxine' $=\frac{y}{x} \times \frac{5}{4} \times 100 \%$.

Thyroxine ${ }^{131} \mathrm{I}$ was obtained from the Radiochemical Centre, Amersham, stored at $-4^{\circ} \mathrm{C}$. in aqueous propyleme glycol, and not used longer than three weeks after delivery. Before use the required quantity was added to a lit diluted plasma and then shaken with Amberlite IRA-400

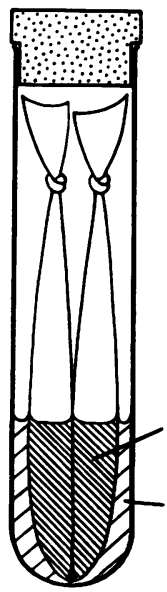

FIG. 1. Doubled cellophane tubing closed with a knot at each end and placed so that fluid levels inside and ou? are the same.

2ml. PLASMA

$+1^{|3|} T 4$

2ml. PLASMA 
resin to remove free iodide (10 - $20 \%$ of the activity). From the resulting product approximately $0.25 \%$ of the activity was dialysable as free iodide after 16 hours.

The volume of plasma normally used was $2 \mathrm{ml}$. inside and $2 \mathrm{ml}$. outside the tubing giving an area of tubing for dialysis of $5.4 \mathrm{sq} . \mathrm{cm}$. (approximately) per $\mathrm{ml}$. Using $1 \mathrm{ml}$. the surface area for dialysis was 5.9 sq. $\mathrm{cm}$. (approximately), and dialysable thyroxine was found to be $10 \%$ higher (mean of 24 estimations). The surface area for dialysis per millilitre of plasma is larger when a smaller volume is used, probably because the test tubes are round bottomed (with the dialysis tubing pushed well down to the bottom). The height of the fluid level, which determines the area of tubing available for dialysis, in such a test tube containing $2 \mathrm{ml}$. total liquid is slightly more than half the height of the fluid level when the tube contains a total of $4 \mathrm{ml}$.

The amount of thyroxine dialysed was not found to be exactly proportional to time, dialysis tending to become a little more rapid. After 24 hours bacterial growth occurs, and 16 hours was selected as a convenient time.

Different samples of Amberlite IRA-400 resin were tested and none were found to absorb appreciable quantities of ${ }^{131}$ I thyroxine added to plasma after the preparation described above.

A number of estimations of dialysable tri-iodothyronine were made by the same method; although the quantity dialysed was greater, the discrimination of thyroid states was less satisfactory.

\section{RESULTS}

Eighteen-hour dialysable thyroxine was estimated by the method described in patients whose thyroid status was established clinically, with radio-iodine studies, and with other tests, and in a few patients in normal pregnancy (Fig. 2.) In the majority the triiodothyronine binding coefficient (Adams, Specht, and Woodward, 1960) was also estimated by the method of Hamolsky, Golodetz, and Freedberg (1959) and the results are compared (Fig. 3). In these

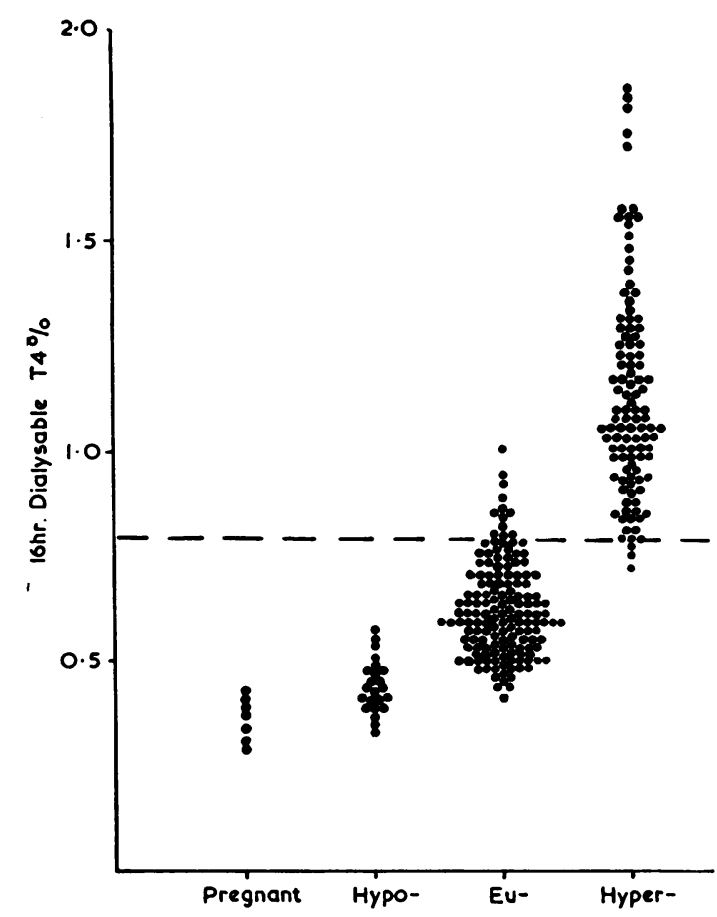

FIG. 2. Thyroid status and 16-hour dialysable thyroxine.

patients the distinction between normal and hyperthyroid (more than $0.80 \%$ dialysable in 16 hours or T3 binding coefficient over $0 \cdot 115$ ) was made a little more successfully by dialysable thyroxine than by tri-iodothyronine binding coefficient; the differentiation of hypothyroidism was less satisfactory by both methods.

TABLE I

INDICES OF THYROID STATUS OBTAINED BY DIALYSABLE THYROXINE

\begin{tabular}{|c|c|c|c|}
\hline Series & 16-Hour Dialysable Thyroxine (\%) & $\begin{array}{l}\text { Chemical Protein-bound Iodine } \\
\text { ( } \mathrm{gg} . \%)\end{array}$ & $\begin{array}{l}\text { Dialysable Thyroxine } \times \text { Chemical } \\
\text { Protein-bound lodine }\end{array}$ \\
\hline Hypothyroid & $\begin{array}{l}0.34 \\
0.52 \\
0.44 \\
0.45 \\
0.41\end{array}$ & $\begin{array}{l}3.1 \\
3.5 \\
3.0 \\
1.0 \\
2.4\end{array}$ & $\begin{array}{l}1.1 \\
1.8 \\
1.3 \\
0.45 \\
1.0\end{array}$ \\
\hline Pregnant & $\begin{array}{l}0.30 \\
0 \cdot 38\end{array}$ & $\begin{array}{l}9.0 \\
9 \cdot 4\end{array}$ & $\begin{array}{l}2 \cdot 7 \\
3 \cdot 6\end{array}$ \\
\hline Euthyroid & $\begin{array}{l}0.61 \\
0.49 \\
0.47 \\
0.67 \\
0.75\end{array}$ & $\begin{array}{l}6 \cdot 4 \\
7.5 \\
8 \cdot 7 \\
6 \cdot 3 \\
6 \cdot 0\end{array}$ & $\begin{array}{l}3.9 \\
3 \cdot 7 \\
4 \cdot 1 \\
4 \cdot 2 \\
4 \cdot 5\end{array}$ \\
\hline Hyperthyroid & $\begin{array}{l}1.06 \\
1.17 \\
0.89\end{array}$ & $\begin{array}{r}9 \cdot 6 \\
12 \cdot 3 \\
10 \cdot 2\end{array}$ & $\begin{array}{r}10.2 \\
14.4 \\
9.1\end{array}$ \\
\hline
\end{tabular}


TABLE II

RESULTS BY DIALYSABLE THYROXINE COMPARED WITH THOSE WITH OTHER METHODS

\begin{tabular}{|c|c|c|c|c|c|}
\hline \multirow[t]{2}{*}{ Series } & \multicolumn{2}{|c|}{ Dialysable T4 (\%) } & \multirow{2}{*}{$\begin{array}{l}\text { Free T4 \% (Sterling } \\
\text { and Hegedus, 1962) }\end{array}$} & \multirow{2}{*}{$\begin{array}{l}\text { Resin uptake of T3\% } \\
\text { (Sterling and } \\
\text { Tabachnick, 1961) }\end{array}$} & \multirow{2}{*}{$\begin{array}{l}\text { T3 Binding Coeffici } \\
\text { (present series) }\end{array}$} \\
\hline & Present Series & Christensen (1959) & & & \\
\hline
\end{tabular}

In some patients dialysable thyroxine and chemical

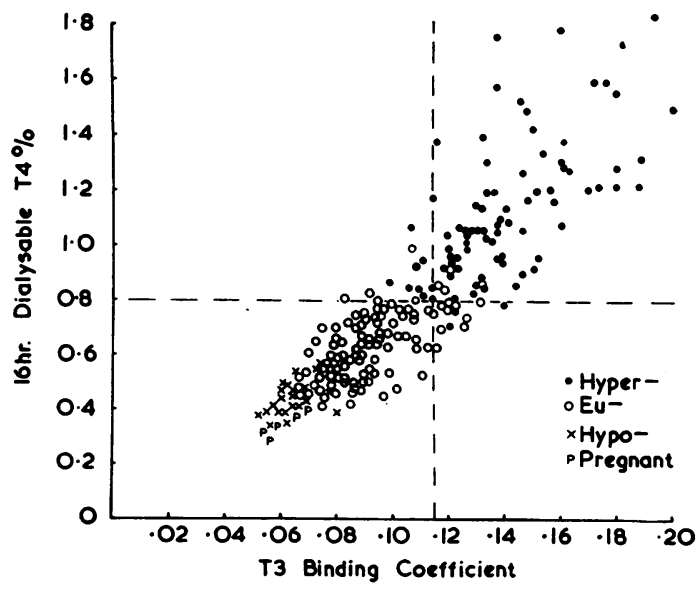

FIG. 3. Sixteen-hour dialysable thyroxine compared with tri-iodothyronine-binding coefficient. protein-bound iodine were estimated. The produgts promises to give a good index of thyroid statu (Table I).

Finally the results of the technique described above are compared with other similar or related, methods (Table II).

The method of Christensen was comparable except that dialysis was carried out for a longer time (24 hours) across a relatively smaller surface (approxes mately $2.9 \mathrm{~cm} .{ }^{2} / \mathrm{ml}$.). All the methods give results for different thyroid states which are in proportion.

Adams, R., Specht, N., and Woodward, I. (1960). J. clin. Endocr., 20, 1366.

Christensen, L. K. (1959), Scand. J. clin. Lab. Invest., 11, 326.

Ekins, R. P. (1960). Clin. chim. Acta, 5, 453.

Hamolsky, M. W., Golodetz, A., and Freedberg, A. S. (1959). J. cliph Endocr., 19, 103.

Owen, G. M. (1960). Phys. in Med. Biol., 5, 183.

Robbins, J. (1956). Arch. Biochem., 63, 461.

Sterling, K., and Hegedus, A. (1962). J. clin. Invest., 41, 1031. - , and Tabachnick, M. (1961). J. clin. Endocr., 21, 456.

(1) ర్⿻ $\frac{2}{2}$ 